\title{
THE EFFECTS OF GAMMA-RADIATION ON CROSSES BETWEEN LOLIUM PERENNE AND FESTUCA PRATENSIS
}

\author{
J. D. H. REUSCH
}

Department of Agricultural Botany, University College of Wales, Aberystwyth*

Received 23.ii.59

\section{INTRODUCTION}

SEED-INCOMPATIBILITy, which relates to failure of normal seed development in consequence of impaired endosperm development (Valentine, 1953), has been reported in a wide variety of interspecific crosses, especially among the Graminex. It is due either to chromosomal or to genic differences between the genomes of the species involved in the cross, and has been shown to be in large measure responsible for the reproductive isolation which exists between the two related grass species Lolium perenne ( $2 n=14)$ and Festuca pratensis $(2 n=14)$ (Reusch, I $959 b$ ). Thus, where in crosses L. perenne is used as the seed parent, endosperm development is normal until approximately 72 hours after pollination, but thereafter precocious cell formation in the tissue markedly retards further nuclear division. In reciprocal crosses, on the other hand, cell formation does not occur, but mitotic irregularities eventually lead to the complete disintegration of the endosperm. In the latter case none of the seeds is viable, but in the former some of the caryopses may germinate, depending upon the amount of endosperm formed before cell formation.

Although with the evidence available at present, the possibility of cryptic structural differences between the chromosomes of $L$. perenne and $F$. pratensis cannot be ruled out, it appears that evolutionary divergence between these two species has been mainly genic. For example, it has been shown that in $\mathrm{F}_{1}$ hybrids, pairing of the chromosomes is normal, and further, that the chiasma frequency of the hybrids closely approximates that of the parental species (Peto, 1933). Significant differences in seed-compatibility between various genotypic combinations of the two species have also been demonstrated (Reusch, I959a).

It was therefore considered possible that ionising radiations could induce gene changes which might break down the barrier to hybridisation. The results presented here indicate that, in certain instances at least, ionising radiations did reduce the degree of seedincompatibility.

* Present address : College of Agriculture, P.O. Cedara, Natal, South Africa. 


\section{MATERIALS AND METHODS}

Three genotypes each of $L$. perenne and $F$. pratensis, which differed widely in their interspecific seed-compatibility (Reusch, I959a) were used for the crosses, namely :

$\begin{array}{cc}\text { L. perenne } & F . \text { pratensis } \\ \text { I } 787 \mathrm{bA}(\mathrm{I})_{3}-\mathrm{LI}_{1} & 4 \mathrm{I}(35)-\mathrm{F}_{1} \\ \text { I } 194 \mathrm{bA}(\mathrm{I})_{3}-\mathrm{L}_{2} & 324(\mathrm{I} 5)-\mathrm{F}_{2} \\ \mathrm{Ba}_{4952}(\mathrm{I} 6)-\mathrm{L}_{3} & 325(8)-\mathrm{F}_{3}\end{array}$

The system of designation is that employed at the Welsh Plant Breeding Station, Aberystwyth, but for convenience the symbols $\mathrm{L}_{1}, \mathrm{~L}_{2}$ and $\mathrm{L}_{3}$, and $\mathrm{F}_{1}, \mathrm{~F}_{2}$ and $\mathrm{F}_{3}$ will be used throughout.

As a source of gamma rays Cobalt ${ }^{60}$ was used, and five different doses, all given over a period of one hour, were applied, namely 250r, 50or, Iooor, 200or, and 30oor.

The inflorescences were treated about 7 days prior to anthesis, care being taken that they were all at approximately the same stage of development.

All units for any particular cross (generally consisting of approximately 300 florets) were emasculated on the same day, and the pollinations were commenced at strictly comparable times so as to eliminate possible environmental effects on endosperm development (Reusch, I959c).

Two criteria of interspecific compatibility were employed, namely :

(a) Seed set : all ovaries showing definite signs of development were recorded as having sct seed.

(b) Seed viability : all caryopses showing any signs of germination, however weak, were recorded as viable. Since the ability of seeds to germinate is dependent on the presence of at least a small amount of endosperm, the germination data provide an estimate of the seed-compatibility of the various genotypic combinations.

It should be noted that the seed-setting results are based on the total number of florets emasculated, whereas the germination data are expressed as a percentage of the total number of caryopses formed. To a certain degree the two estimates are therefore independent, since it is for example possible to obtain a high germination percentage even when seed-set is low.

\section{OBSERVATIONS}

(a) The effect of pollen irradiation on compatibility

(i) Seed-set. Results on the effect of pollen irradiation on seed-set are given in table I. An analysis of the original data showed that except for the crosses $\mathrm{F}_{3} \times \mathrm{L}_{\mathrm{I}}$ and $\mathrm{F}_{3} \times \mathrm{L}_{3}$, overall differences between treatments were in all cases significant. However, only in the case of three combinations, namely $\mathrm{L}_{\mathrm{I}} \times \mathrm{F}_{2}, \mathrm{~F}_{\mathrm{I}} \times \mathrm{L}_{2}$ and $\mathrm{F}_{3} \times \mathrm{L}_{2}$, did seedset improve as a result of irradiation.

A general feature of the effect of irradiation was a reduction in seed-set at doses of 250-50or. This was followed by an increase at I ooo-200or, but further increases in dose again resulted in a decline.

(ii) Seed-viability. The effects of pollen irradiation on seed-viability, although similar to those observed for seed-set, showed greater variability (table I). If, however, one takes into account the direction of the cross and the normal seed-compatibility of the genotypes, the results still seem to fit into a general pattern. 
In the $L$. perenne $\times F$. pratensis matings (fig. I), both the decrease in seed-viability at 250-50or and the recovery at $1000-2000$ occurred

TABLE I

The effect of pollen irradiation on seed-set and seed-viability in crosses between different genotypes of $\mathrm{L}$. perenne and $\mathrm{F}$. pratensis

\begin{tabular}{|c|c|c|c|c|c|c|c|c|}
\hline \multirow{2}{*}{\multicolumn{2}{|c|}{$\begin{array}{l}\text { Genotype } \\
\text { combination }\end{array}$}} & \multicolumn{6}{|c|}{$\begin{array}{c}\text { Percentage seed-set and germination } \\
\text { at different doses of } \\
\gamma \text {-rays }\end{array}$} & \multirow[t]{2}{*}{$\chi^{2}(s)$} \\
\hline & & Control & 25 or & 5oor & Iooor & $2000 \mathrm{r}$ & 3 ooor & \\
\hline 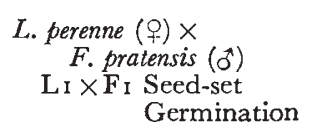 & $\dot{.}$ & $\begin{array}{r}77 \cdot 6 \\
0 \cdot 0\end{array}$ & $\begin{array}{r}62 \cdot 8 \\
0 \cdot 0\end{array}$ & $\begin{array}{r}66 \cdot 1 \\
0 \cdot 0\end{array}$ & $\begin{array}{r}59 \cdot 0 \\
0 \cdot 0\end{array}$ & $\begin{array}{r}49^{\circ} \circ \\
0 \cdot 0\end{array}$ & $\begin{array}{r}47 \cdot 7 \\
0 \cdot 0\end{array}$ & $\begin{array}{c}65 \cdot 4 \dagger \\
\ldots\end{array}$ \\
\hline $\mathrm{L}_{1} \times \mathrm{F}_{2} \underset{\text { Germination }}{\text { Seed-set }}$ & $\dot{.}$ & $\begin{array}{r}6 \mathrm{I} \cdot 8 \\
0 \cdot 0\end{array}$ & $\begin{array}{r}79 \cdot 2 \\
0 \cdot 0\end{array}$ & $\begin{array}{r}8 I \cdot 3 \\
0 \cdot 0\end{array}$ & $\begin{array}{r}76 \cdot 2 \\
0 \cdot 0\end{array}$ & $\begin{array}{r}83 \cdot 2 \\
0 \cdot 0\end{array}$ & $\begin{array}{r}83 \cdot 7 \\
0 \cdot 0\end{array}$ & $\begin{array}{c}45 \cdot 7 \dagger \\
\ldots\end{array}$ \\
\hline $\mathrm{L}_{\mathrm{I}} \times \mathrm{F}_{3} \underset{\text { Germination }}{\text { Seed-set }}$ & : & $\begin{array}{r}74 \cdot 9 \\
0 \cdot 0\end{array}$ & $\begin{array}{r}73 \cdot 1 \\
0 \cdot 0\end{array}$ & $\begin{array}{r}66 \cdot 7 \\
0 \cdot 0\end{array}$ & $\begin{array}{r}79 \cdot 3 \\
0 \cdot 0\end{array}$ & $\begin{array}{r}80 \cdot 9 \\
0 \cdot 0\end{array}$ & $\begin{array}{r}67 \cdot 2 \\
0 \cdot 0\end{array}$ & $\begin{array}{c}22 \cdot 4 \dagger \\
\ldots\end{array}$ \\
\hline $\mathrm{L}_{2} \times \mathrm{F}_{1} \underbrace{\text { Seed-set }}_{\text {Germination }}$ & $\dot{.}$ & $\begin{array}{l}8 I \cdot 5 \\
10 \cdot 8\end{array}$ & $\begin{array}{r}70 \cdot 5 \\
7 \cdot 6\end{array}$ & $\begin{array}{r}65 \cdot 2 \\
8 \cdot 0\end{array}$ & $\begin{array}{l}8 \mathrm{I} \cdot \mathrm{I} \\
\mathrm{I} \mathrm{I} \cdot 9\end{array}$ & $\begin{array}{r}86 \cdot 3 \\
8 \cdot 8\end{array}$ & $\begin{array}{r}73 \cdot 1 \\
6 \cdot 5\end{array}$ & $\begin{array}{c}46 \cdot 1 \dagger \\
5 \cdot 1\end{array}$ \\
\hline $\mathrm{L}_{2} \times \mathrm{F}_{3} \underset{\text { Geed-set }}{\text { Sermination }}$ & . & $\begin{array}{l}85 \cdot 0 \\
17 \cdot 6\end{array}$ & $\begin{array}{l}80 \cdot 3 \\
24 \cdot 1\end{array}$ & $\begin{array}{r}70 \cdot 8 \\
6 \cdot 8\end{array}$ & $\begin{array}{l}84 \cdot 8 \\
15 \cdot 1\end{array}$ & $\begin{array}{l}82 \cdot 9 \\
12 \cdot 0\end{array}$ & $\begin{array}{l}73 \cdot 2 \\
10 \cdot 9\end{array}$ & $\begin{array}{l}26 \cdot 5 \dagger \\
26 \cdot 7 \dagger\end{array}$ \\
\hline $\mathrm{L}_{3} \times \mathrm{F}_{\mathrm{I}} \underbrace{\text { Seed-set }}_{\text {Germination }}$ & $\dot{\bullet}$ & $\begin{array}{l}76 \cdot 7 \\
46 \cdot 3\end{array}$ & $\begin{array}{l}73 \cdot 7 \\
25 \cdot 6\end{array}$ & $\begin{array}{r}66 \cdot 0 \\
6 \cdot 9\end{array}$ & $\begin{array}{l}83 \cdot 6 \\
17 \cdot 3\end{array}$ & $\begin{array}{l}78 \cdot 6 \\
31 \cdot 6\end{array}$ & $\begin{array}{l}60 \cdot 8 \\
20 \cdot 0\end{array}$ & $\begin{array}{l}44 \cdot 9 \dagger \\
90 \cdot 7 \dagger\end{array}$ \\
\hline $\mathrm{L}_{3} \times \mathrm{F}_{2} \underset{\text { Germination }}{\text { Seed-set }}$ & $\dot{\bullet}$ & $\begin{array}{l}84 \cdot 4 \\
44 \cdot 9\end{array}$ & $\begin{array}{l}72 \cdot 5 \\
40 \cdot 6\end{array}$ & $\begin{array}{l}5^{8 \cdot 6} \cdot 6 \\
37 \cdot 9\end{array}$ & $\begin{array}{l}81 \cdot 1 \\
54 \cdot 7\end{array}$ & $\begin{array}{l}64 \cdot 5 \\
38 \cdot 7\end{array}$ & $\begin{array}{l}49 \cdot 6 \\
3^{8} \cdot 1\end{array}$ & $\begin{array}{l}94 \cdot 4 \dagger \\
12 \cdot 3\end{array} *$ \\
\hline $\mathrm{L}_{3} \times \mathrm{F}_{3} \underset{\text { Geed-set }}{\text { Germination }}$ & $\dot{r}$ & $\begin{array}{l}76 \cdot 8 \\
54 \cdot 1\end{array}$ & $\begin{array}{l}76 \cdot 3 \\
46 \cdot 7\end{array}$ & $\begin{array}{l}74 \cdot 7 \\
42 \cdot 1\end{array}$ & $\begin{array}{l}76 \cdot 8 \\
62 \cdot 0\end{array}$ & $\begin{array}{l}67 \cdot 4 \\
64 \cdot 3\end{array}$ & $\begin{array}{l}66 \cdot 0 \\
62 \cdot 7\end{array}$ & $\begin{array}{l}\text { I5.I } † \\
3 \mathrm{I} \cdot 3 \dagger\end{array}$ \\
\hline 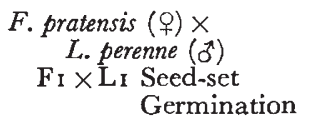 & . & $\begin{array}{r}71 \cdot 7 \\
0 \cdot 9\end{array}$ & $\begin{array}{r}45 \cdot 6 \\
0 \cdot 0\end{array}$ & $\begin{array}{r}50 \cdot 0 \\
2 \cdot 1\end{array}$ & $\begin{array}{r}6 r \cdot 3 \\
r \cdot 8\end{array}$ & $\begin{array}{r}39 \cdot 8 \\
0 \cdot 0\end{array}$ & $\begin{array}{l}25 \cdot 0 \\
14 \cdot 3\end{array}$ & $\begin{array}{r}174.6 \dagger \\
58 \cdot 0 \dagger\end{array}$ \\
\hline $\mathrm{F}_{1} \times \mathrm{L}_{2} \underset{\text { Geed-set }}{\text { Sermination }}$ & . & $\begin{array}{r}54 \cdot 8 \\
0 \cdot 0\end{array}$ & $\begin{array}{l}73 \cdot 2 \\
13 \cdot 4\end{array}$ & $\begin{array}{r}56 \cdot 6 \\
7 \cdot 1\end{array}$ & $\begin{array}{r}30 \cdot 7 \\
4 \cdot 1\end{array}$ & $\begin{array}{r}43 \cdot 4 \\
6 \cdot 4\end{array}$ & $\begin{array}{r}4^{8 \cdot 0} \\
0 \cdot 0\end{array}$ & $\begin{array}{r}\operatorname{IOg} \cdot 5 \dagger \\
35 \cdot 2 \dagger\end{array}$ \\
\hline $\mathrm{F}_{2} \times \mathrm{L}_{3} \underset{\text { Geed-set }}{\text { Germination }}$ & . & $\begin{array}{r}6 I \cdot 2 \\
0 \cdot 0\end{array}$ & $\begin{array}{r}5 I \cdot 6 \\
0 \cdot 0\end{array}$ & $\begin{array}{r}50 \cdot 5 \\
0 \cdot 0\end{array}$ & $\begin{array}{r}5 \mathrm{I} \cdot 5 \\
0 \cdot 0\end{array}$ & $\begin{array}{r}57 \cdot 6 \\
0 \cdot 0\end{array}$ & $\begin{array}{r}4^{6 \cdot 9} \cdot 9 \\
0 \cdot 0\end{array}$ & $\begin{array}{l}14 \cdot 0 * \\
\cdots\end{array}$ \\
\hline $\mathrm{F}_{3} \times \mathrm{L}_{\mathrm{I}} \begin{array}{l}\text { Seed-set } \\
\text { Germination }\end{array}$ & : & $\begin{array}{r}53 \cdot 5 \\
0.0\end{array}$ & $\begin{array}{r}52 \cdot 3 \\
0 \cdot 0\end{array}$ & $\begin{array}{r}4^{8 \cdot 7} \\
0 \cdot 0\end{array}$ & $\begin{array}{r}58 \cdot 3 \\
0 \cdot 0\end{array}$ & $\begin{array}{r}54 \cdot 8 \\
0 \cdot 0\end{array}$ & $\begin{array}{r}5 \mathrm{I} \cdot 4 \\
0 \cdot 0\end{array}$ & $\begin{array}{l}5 \cdot 6 \\
\cdots\end{array}$ \\
\hline $\mathrm{F}_{3} \times \mathrm{L}_{2} \underset{\text { Geed-set }}{\text { Sermination }}$ & . & $\begin{array}{r}43 \cdot 8 \\
0 \cdot 0\end{array}$ & $\begin{array}{r}55 \cdot 6 \\
0 \cdot 0\end{array}$ & $\begin{array}{r}62 \cdot 8 \\
6 \cdot 1\end{array}$ & $\begin{array}{r}6 \mathrm{I} \cdot 0 \\
\mathrm{I} \cdot 3\end{array}$ & $\begin{array}{r}22 \cdot 3 \\
0 \cdot 0\end{array}$ & $\begin{array}{r}13 \cdot 3 \\
0 \cdot 0\end{array}$ & $\begin{array}{r}220 \cdot 0 \dagger \\
35 \cdot 6 \dagger\end{array}$ \\
\hline $\mathrm{F}_{3} \times \mathrm{L}_{3} \underset{\text { Germination }}{\text { Seed-set }}$ & . & $\begin{array}{r}60 \cdot 3 \\
0 \cdot 0\end{array}$ & $\begin{array}{r}57 \cdot 0 \\
0 \cdot 0\end{array}$ & $\begin{array}{r}50 \cdot 4 \\
0 \cdot 0\end{array}$ & $\begin{array}{r}56 \cdot 2 \\
0 \cdot 0\end{array}$ & $\begin{array}{r}52 \cdot 6 \\
0 \cdot 0\end{array}$ & $\begin{array}{r}50 \cdot 0 \\
0 \cdot 0\end{array}$ & $\begin{array}{l}8 \cdot 8 \\
\ldots\end{array}$ \\
\hline
\end{tabular}

$$
* \mathrm{P}=0.05-0.01 . \quad+\mathrm{P}=\leqq 0 \cdot 0 \mathrm{r} \text {. }
$$

to varying degrees in different crosses: in the normally incompatible combinations, namely $\mathrm{L}_{\mathrm{I}} \times \mathrm{F}_{\mathrm{I}}, \mathrm{L}_{\mathrm{I}} \times \mathrm{F}_{2}$ and $\mathrm{L}_{\mathrm{I}} \times \mathrm{F}_{3}$, and in the cross D 2 


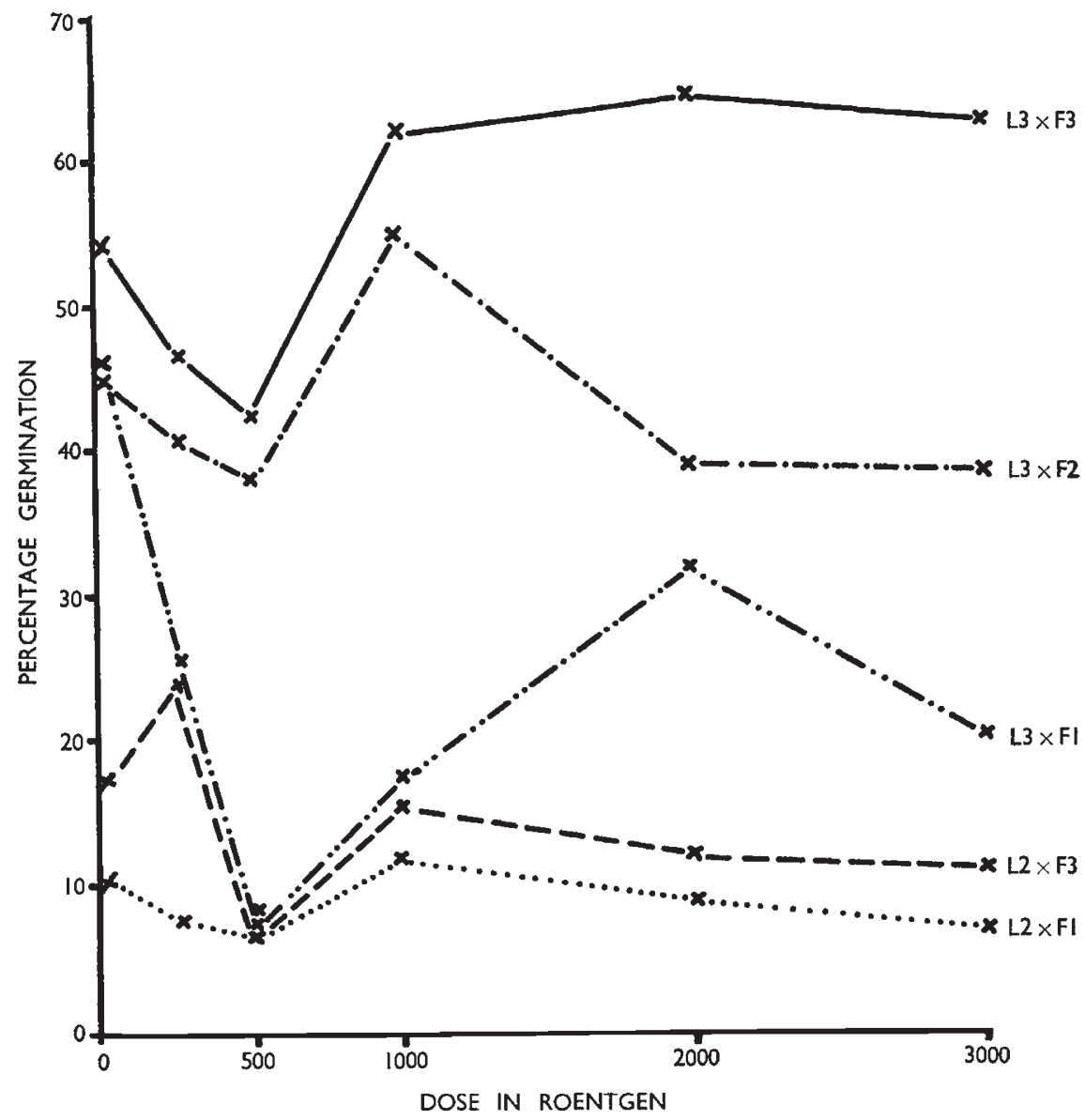

FIG. I-The effect of pollen irradiation on seed-viability in crosses of $L$. perenne $\times F$. pratensis.

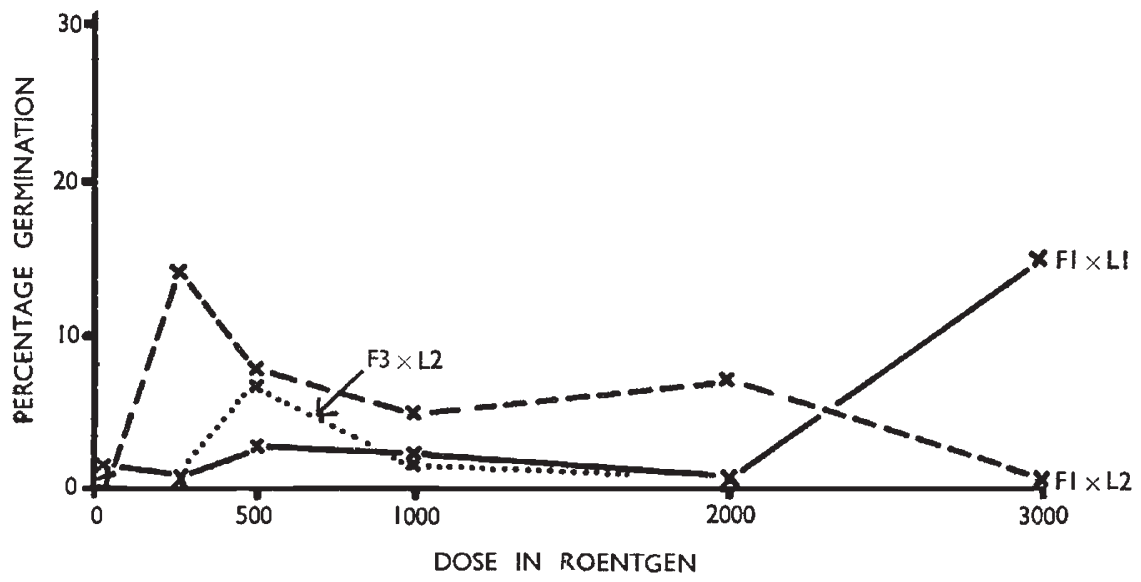

FIG. 2-The effect of pollcn irradiation on seed-viability in crosses of $F$. pratensis $\times L$. perenne. 
of low compatibility $\left(\mathrm{L}_{2} \times \mathrm{F}_{\mathrm{I}}\right)$, irradiation had no significant effect; in the cross of medium compatibility $\left(\mathrm{L}_{2} \times \mathrm{F}_{3}\right)$ and in one of the crosses of high compatibility $\left(\mathrm{L}_{3} \times \mathrm{F}_{\mathrm{I}}\right)$, a marked reduction in viability occurred at 5oor, but the germination percentage at the higher doses did not exceed that observed in controls; in the remaining two crosses of high compatibility $\left(\mathrm{L}_{3} \times \mathrm{F}_{2}\right.$ and $\left.\mathrm{L}_{3} \times \mathrm{F}_{3}\right)$ only a small reduction occurred at 5oor. Moreover, in the latter combinations seed-viability at sooor in the one case, and at doses higher than Iooor in the other, markedly exceeded that of the controls. Genotypic differences in the response to irradiation are therefore evident.

\section{TABLE 2}

The effect of ovule irradiation on seed-set and seed-viability in crosses between different genotypes of $\mathrm{L}$. perenne and $\mathrm{F}$. pratensis

\begin{tabular}{|c|c|c|c|c|c|c|c|}
\hline \multirow{2}{*}{$\begin{array}{l}\text { Genotype } \\
\text { combination }\end{array}$} & \multicolumn{6}{|c|}{$\begin{array}{l}\text { Percentage seed-set and germination } \\
\text { at different doses of } \\
\gamma \text {-rays }\end{array}$} & \multirow{2}{*}{$\chi^{2}(5)$} \\
\hline & Control & 25 or & 5oor & Iooor & $2000 \mathrm{r}$ & 300or & \\
\hline $\begin{array}{l}\text { L. perenne }(\text { (ᄋ) }) \times \\
F . \text { pratensis }\left(0^{*}\right) \\
\text { L2 } 2 \times F_{1} \text { Seed-set } \\
\text { Germination }\end{array}$ & $\begin{array}{r}78 \cdot 4 \\
4 \cdot 0\end{array}$ & $\begin{array}{r}73 \cdot 6 \\
2 \cdot 5\end{array}$ & $\begin{array}{r}70 \cdot 3 \\
3.8\end{array}$ & $\begin{array}{r}68 \cdot 1 \\
7 \cdot 5\end{array}$ & $\begin{array}{r}49 \cdot 7 \\
2 \cdot 1\end{array}$ & $\begin{array}{r}44 \cdot 3 \\
1 \cdot 0\end{array}$ & $\begin{array}{l}54 \cdot 0 \dagger \\
\text { II.7 }\end{array}$ \\
\hline $\mathrm{L}_{3} \times \mathrm{F}_{3} \begin{array}{l}\text { Seed-set } \\
\text { Germination }\end{array}$ & $\begin{array}{l}78 \cdot 5 \\
59 \cdot 4\end{array}$ & $\begin{array}{l}66 \cdot 4 \\
4^{8 \cdot 0}\end{array}$ & $\begin{array}{l}65 \cdot 5 \\
5^{1} \cdot 7\end{array}$ & $\begin{array}{l}51 \cdot 0 \\
27 \cdot 1\end{array}$ & $\begin{array}{l}37 \cdot 8 \\
18 \cdot 1\end{array}$ & $\begin{array}{l}34 \cdot 2 \\
16 \cdot 0\end{array}$ & $\begin{array}{r}\mathrm{r} 4.1 \cdot 3 \dagger \\
97 \cdot 0 \dagger\end{array}$ \\
\hline $\begin{array}{c}\text { F. pratensis }(9) \times \\
\text { L. perenne }\left(\sigma^{*}\right) \\
\text { FI } \times \text { L2 Seed-set } \\
\text { Germination }\end{array}$ & $\begin{array}{r}57 \cdot 0 \\
1 \cdot 3\end{array}$ & $\begin{array}{r}55 \cdot 9 \\
6 \cdot 3\end{array}$ & $\begin{array}{r}53 \cdot 3 \\
7 \cdot 0\end{array}$ & $\begin{array}{r}46 \cdot 0 \\
3 \cdot 2\end{array}$ & $\begin{array}{r}47^{\circ} \cdot 0 \\
I \cdot 0\end{array}$ & $\begin{array}{r}42 \cdot 5 \\
4 \cdot 7\end{array}$ & $\begin{array}{l}24 \cdot 7 \dagger \\
16 \cdot 1 \dagger\end{array}$ \\
\hline $\mathrm{F}_{3} \times \mathrm{L}_{3} \begin{array}{l}\text { Seed-set } \\
\text { Germination }\end{array}$ & $\begin{array}{r}62 \cdot 5 \\
0 \cdot 0\end{array}$ & $\begin{array}{r}46 \cdot 5 \\
0 \cdot 0\end{array}$ & $\begin{array}{r}42 \cdot 7 \\
0 \cdot 0\end{array}$ & $\begin{array}{r}40 \cdot 5 \\
0 \cdot 0\end{array}$ & $\begin{array}{r}33 \cdot 9 \\
0 \cdot 0\end{array}$ & $\begin{array}{r}27 \cdot 3 \\
0 \cdot 0\end{array}$ & $\begin{array}{c}77.2 \dagger \\
\ldots\end{array}$ \\
\hline
\end{tabular}

In the crosses with $F$. pratensis as seed parent (fig. 2), two factors partially conceal the effects of irradiation. Firstly, crosses showing a high degree of seed-compatibility where $L$. perenne is used as seed parent are not the most successful combinations in reciprocal matings. Secondly, the reduction in seed-compatibility at 250-50or, if it does occur, cannot be observed, since no viable seeds are produced when untreated pollen is used. Nevertheless, there is still some evidence for genotypic differences in the response to irradiation, in that the greater the genetic difference between genotypes, the greater was the dose required for optimum viability. For example, $\mathrm{L}_{\mathrm{I}}$ and $\mathrm{F}$ I are, on the basis of $L$. perenne $\times F$. pratensis crosses, more incompatible, and hence probably more divergent genetically, than $\mathrm{L}_{2}$ and $\mathrm{F}_{\mathrm{I}}$. In the former, the greatest viability was obtained at 3ooor, in the latter at 250-50or. 
(b) The effect of ovule irradiation on compatibility

Table 2 and fig. 3 show results on the effect of ovule irradiation for two series of reciprocal crosses. In both $L$. perenne $\times F$. pratensis and $F$. pratensis $\times L$. perenne crosses, seed-set decreased with dose. A similar overall response was observed for seed-viability in the $L$. perenne $\times F$. pratensis combination $\mathrm{L}_{3} \times \mathrm{F}_{3}$, the slight increase at 5 oor being non-significant. In $\mathrm{L}_{2} \times \mathrm{F}_{\mathrm{I}}$, on the other hand, viability at

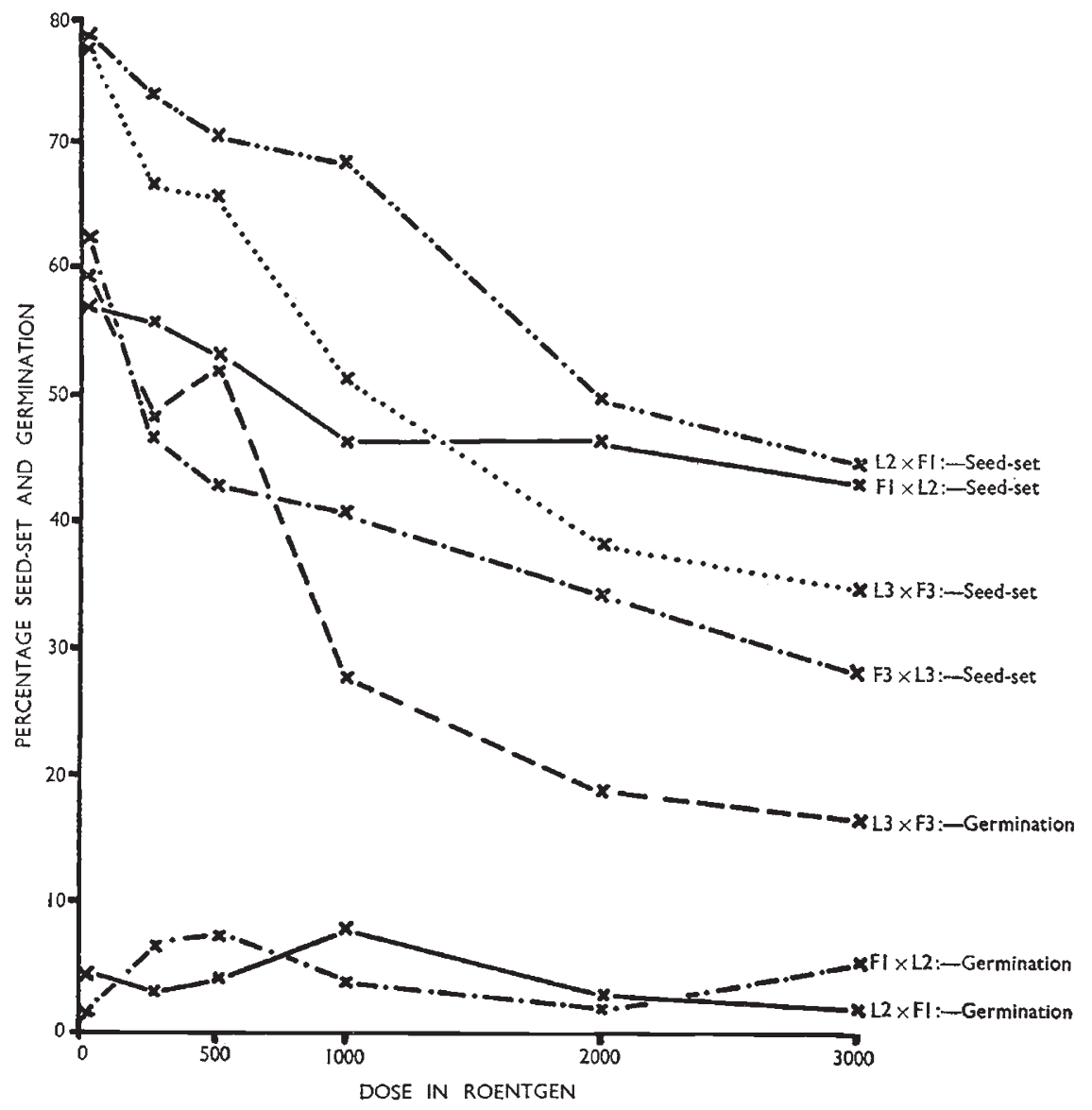

Frg. 3-The effect of ovule irradiation on seed-set and seed-viability in crosses between $L$. perenne and $F$. pratensis.

Iooor was significantly higher than at 25or, but not significantly higher than in the control. It should be noted that normal viability in the latter cross was low compared with the former.

In one of the $F$. pratensis $\times L$. perenne crosses analysed, namely $\mathrm{F}_{3} \times \mathrm{L}_{3}$, ovule irradiation had no effect. In the other $\left(\mathrm{F}_{1} \times \mathrm{L}_{2}\right)$ a significant increase in viability occurred up to 5 oor, after which there was a decrease. The slight increase at 3000 was not significant. 


\section{(c) Endosperm development following irradiation}

In order to determine the nature of the effect of irradiation on seedcompatibility, a single cross, namely $\mathrm{L}_{3} \times \mathrm{F}_{3}$, was examined embryologically following the use of pollen treated with 3 ooor. In this combination, as shown above, seed-viability at the higher doses of irradiation was greater than that where untreated pollen was used. Table 3 gives the mean number of endosperm nuclei at fixed intervals after pollination. Results following the use of untreated $F_{3}$ pollen and untreated intraspecific pollen are also given.

Up to 48 hours after pollination the rate of endosperm development in the two crosses did not differ from that in the control. By 72 hours, however, a stage at which precocious cell formation takes place in the endosperm of hybrid seeds (Reusch, I $959^{b}$ ) the number of endosperm

TABLE 3

Mean number of endosperm nuclei in the L. perenne genotype $L_{3}$, and in the cross $L_{3} \times F_{3}$ following pollination with both treated and untreated pollen

\begin{tabular}{|c|c|c|c|c|c|c|}
\hline \multirow{2}{*}{$\begin{array}{l}\text { Control and } \\
\text { crosses }\end{array}$} & \multicolumn{6}{|c|}{$\begin{array}{l}\text { Mean number of endosperm nuclei at } \\
\text { different times after pollination }\end{array}$} \\
\hline & $\begin{array}{c}12 \\
\text { hours }\end{array}$ & $\begin{array}{ll}24 \\
\text { hours }\end{array}$ & $\begin{array}{c}48 \\
\text { hours }\end{array}$ & $\begin{array}{c}72 \\
\text { hours }\end{array}$ & $\begin{array}{l}96 \\
\text { hours }\end{array}$ & $\begin{array}{l}120 \\
\text { hours }\end{array}$ \\
\hline $\mathrm{L}_{3}$-intraspecific control & $2 \cdot 0$ & $7 \cdot 5$ & $99 \cdot 0$ & $640 \cdot 0$ & I $414^{\circ} \mathrm{O}$ & $2545^{\circ} \mathrm{O}$ \\
\hline $\mathrm{L}_{3} \times \mathrm{F}_{3}$-untreated pollen & $2 \cdot 0$ & $8 \cdot 5$ & IOI'O & $454^{\circ} \mathrm{o}$ & $809 \cdot 0$ & I $527^{\circ} \mathrm{O}$ \\
\hline $\begin{array}{l}\mathrm{L}_{3} \times \mathrm{F}_{3} \text {-pollen treated with } \\
3000 \mathrm{r}\end{array}$ & $2 \cdot 0$ & $8 \cdot 3$ & $105^{\circ} \mathrm{O}$ & $453^{\circ} \mathrm{o}$ & $890 \cdot 0$ & I $775^{\circ} \mathrm{O}$ \\
\hline
\end{tabular}

nuclei in the crosses was lower than that in the control. It is significant that at 96 hours and later, this retardation in endosperm growth rate was less marked when using irradiated pollen.

\section{DISCUSSION}

The purpose of this investigation was primarily to determine the effect of irradiation on seed-compatibility, as measured by viability, but the results have shown clearly that seed-set is also markedly influenced and in a broadly similar manner. On the data available it is difficult to find any single satisfactory explanation for the observed responses. However, the almost regular reduction in seed-viability at the lower doses, followed by an increase, in those crosses where viable caryopses are produced, seem to indicate two separate effects of irradiation. The first effect causes a deterioration of seed-compatibility, while the second brings about an improvement. What is the nature of these effects? Since in crosses between $L$. perenne and $F$. pratensis, seed-incompatibility results from an impaired development 
of the endosperm (Reusch, I959b), it is evident that they must be concerned with the development of the endosperm and the following are suggested: (a) Up to 5oor chromosomally damaged pollen grains are not affected in their functional ability so that they are able to participate in fertilisation and triple fusion. However, as a result of chromosomal abnormalities, degeneration of the embryo and/or endosperm of a proportion of the caryopses sets in soon after fertilisation in a manner similar to that reported in Lilium formosum (Cave and Brown, I954). In consequence, many of the seeds will not be viable. This degeneration presumably accounts for the reduction in viability in crosses of $L$. perenne by $F$. pratensis following pollen treatment with doses of 250-50or, and is therefore not genic. With doses higher than 5 oor, the functional ability of the pollen grains is presumably affected, so that selective elimination of the more severely damaged ones will occur. In consequence there will be a tendency towards a levelling-off of the deleterious effect. In the case of ovules, selective elimination cannot occur, so that their functional ability (measured in terms of the number of ovules which set seed) should decrease with an increase of dose. This did occur. (b) The recovery in seed-compatibility at doses higher than 5 oor is due to a second influence of irradiation, which allows those caryopses, in which chromosomal damage does not lead to a cessation of growth, to develop more endosperm than seeds set following the use of untreated pollen. Since this beneficial effect of irradiation markedly varies with different genotypic combinations, it would appear that gene changes are involved, so that superimposed upon the initial non-genic deleterious effect there is a beneficial genic effect, the nature of which could be explained as follows:

If one accepts that two genotypes, which under normal conditions of interspecific cross-pollination give rise to only a few viable seeds, are genetically more diverse than two which yield a large proportion of germinable caryopses, then, on the basis of a threshold of gene changes for improvement of endosperm development, one would expect that a larger number of gene changes and hence larger dosages of irradiation would be required to bring about an improvement in seed-compatibility in the former than in the latter. That this is the case is clear from the $L$. perenne $\times F$. pratensis crosses (see earlier). On this basis it is also to be expected that in crosses where initial differences are too great, irradiation-induced gene changes will be ineffective in reducing the genetic disparity between the genomes in the endosperm. This would then be the case in those combinations where irradiation had no effect on seed-compatibility.

Since the crosses of $F$. pratensis $\times L$. perenne all produced no viable seeds under normal conditions, it is evident that the deleterious effects of irradiation discussed above cannot be detected. The beneficial effect, on the other hand, was clearly observable, in that a number of the combinations yielded viable seeds following irradiation of both pollen and ovules. 
Following on the above, one further point needs consideration, namely the manner in which endosperm development is influenced. From the L. perenne $\times F$. pratensis cross analysed, it does appear that the degree of suppression of nuclear division, following precocious cell formation, is mainly affected. In consequence a larger amount of endosperm tissue is formed following the use of treated pollen, than in cases where untreated pollen is used. Similar observations have been made on low $\times$ high chromosome species crosses of Avena and Triticum, where better-filled caryopses were obtained with X-irradiated pollen than with untreated pollen (Nishiyama and Iizuka, 1952).

For crosses of $F$. pratensis $\times L$. perenne one must assume that the intensity of abnormal divisions within the endosperm are reduced.

\section{SUMMARY AND CONCLUSIONS}

I. Results are presented on the effect of gamma irradiation on seed-set and seed-viability in reciprocal crosses between $L$. perenne and $F$. pratensis.

2. Following irradiation of the pollen, a reduction occurred in hybrid seed set at doses of 250-50or. This was followed by an increase at 1000-200or, but further increases in dose generally again resulted in a decline. Irradiation of ovules led to a progressive decrease in seed set with increase of dose.

3. In crosses of $L$. perenne $\times F$. pratensis, pollen irradiation, in general, did not raise the germination capacity of the caryopses above that for crosses in which untreated pollen was used. All combinations which gave rise to viable seeds under normal conditions, showed some decrease after irradiation at 5oor, followed by an increase at the higher doses. Both the degree of reduction at 5 oor and the increase at higher doses varied with the genotypes involved in the cross.

4. Where $F$. pratensis was the seed parent, no viable seeds were obtained after pollination with untreated pollen. In three combinations out of six, however, viable seeds were produced as a result of pollen irradiation. Here, genotypic differences in the response to irradiation were also apparent.

5. It is suggested that the initial reduction in seed-viability is a consequence of endosperm degeneration in a proportion of ovules due to fertilisation by chromosomally damaged pollen grains. The increase at the higher doses is considered to be due to gene changes which reduce genetic unbalance within the endosperm, thus allowing for an improved development of the tissue.

6 . It may be concluded that through the agency of ionising radiations, it is possible, in certain instances at least, to reduce the degree of seed-incompatibility. The improvement in viability may, however, be mainly limited to crosses made in one direction. Thus in L. perenne $\times$ $F$. pratensis crosses, the germination capacity of the caryopses was generally not improved, and in incompatible combinations irradiation 
had no effect. In reciprocal matings, on the other hand, viable seeds were obtained from combinations which after normal pollinations gave no germinable caryopses.

Acknowledgments. - I am greatly indebted to Professor P. T. Thomas for encouragement and advice received during the course of these investigations.

I also wish to express my gratitude to Mr P. J. Gildenhuys of the Natal Agricultural Research Institute, Pietermaritzburg, for constructive criticism of the manuscript, and to the South African Department of Agriculture for the financial aid which enabled me to take up these studies at the University College of Wales, Aberystwyth.

\section{REFERENCES}

GAVE, M. s., AND BROWN, s. w. I954. The nature and detection of dominant lethals in Lilium II. Cytological abnormalities in ovules after pollen irradiation. Amer. 7. Bot., 4I, 469-483.

NISHIYAMA, I., AND IIzUKA, M. 1952. Successful hybridisation by means of X-rayed pollen in otherwise incompatible crosses. Bull. Res. Inst. Food Sci., Kyoto Univ., No. 8.

PETO, F. H. 1933. The cytology of certain intergeneric hybrids between Festuca and Lolium. 7. Genetics, 28 , I $13^{-1} 5^{6}$.

REUSCH, J. D. H. I959a. The nature of the genetic differentiation between Lolium perenne and Festuca pratensis. S. Afric. F. Agric. Sci., 2, 271-283.

REUSGH, J. D. H. I959b. Embryological studies on sced-development in reciprocal crosses between Lolium perenne and Festuca pratensis. S. Afric. 7. Agric. Sci. In press.

REUSGH, J. D. H. I959c. Note on the nature of the effect of the environment on seed-viability in interspecific hybrids. S. Afric. 7. Agric. Sci. In press.

VAlentine, D. H. 1953. Evolutionary aspects of species differences in Primula. Symp. Soc. Exp. Biol., 7, I46-1 $5^{8 .}$ 